\title{
Congenital Malformations Associated with Maternal Use of Valproic Acid
}

\author{
Celine Huot, Marie Gauthier, Marc Lebel and Albert Larbrisseau
}

\begin{abstract}
Two children born with birth defects after intrauterine exposure to valproic acid are reported. The mothers took the drug throughout pregnancy as sole treatment for primary generalized epilepsy. The first baby showed facial dysmorphism, arachnodactyly and triphalangeal thumbs. The second had facial dysmorphism, severe laryngeal hypoplasia, tracheomalacia and an aberrant innominate artery that caused tracheal compression. A left superior vena cava, abnormal pulmonary lobulation, and unilateral hydronephrosis were also found at autopsy. Valproic acid has probable teratogenic potential in humans but the number of reported cases is few and the spectrum of anomalies is broad so it is not possible to delineate a definite fetal valproate syndrome.
\end{abstract}

RÉSUMÉ: Malformations congénitales associées à l'utilisation de l'acide valproïque par la mère pendant la grossesse. On rapporte ici les cas de deux enfants nés avec des malformations après une exposition à l'acide valproïque durant leur vie intra-utérine. Les deux mères en cause ont pris de l'acide valproïque durant toute leur grossesse comme traitement unique d'une épilepsie primaire généralisée. Le premier bébé avec un dysmorphisme facial, une arachnodactylie et des pouces triphalangés. Le second avait un dysmorphisme facial, une hypoplasie laryngée sévère, une trachéomalacie et une artère innominée aberrante causant une compression trachéale. A l'autopsie, on constata en outre la présence d'une veine cave supérieure gauche, d'une lobulation pulmonaire anormale et d'une hydronéphrose unilatérale. L'acide valproïque a probablement un potentiel tératogène; cependant, étant donné le peu de cas et le grand nombre d'anomalies rapportées, il n'est pas encore possible de définir un syndrome foetal précis associé à l'acide valproïque.

Can. J. Neurol. Sci. 1987; 14:290-293

Valproic acid, a simple eight-carbon branched chain fatty acid, was initially used in clinical practice to treat petit mal seizures. Thanks to its large spectrum of activity, its use has been broadened to the treatment of other types of seizure disorders, either alone or as an adjunct to other anticonvulsants. Animal studies have shown dose-related teratogenecity with valproic acid..$^{1-3}$ Despite the fact that the incidence of fetal malformations is higher for mothers with epilepsy than for the general population, there has also been some evidence in recent years of teratogenecity from valproic acid when used in this subgroup of the population. ${ }^{4-16} \mathrm{~A}$ possible association with spina bifida was suggested without prospective study. ${ }^{4-6}$ Fortysix malformed babies born to mothers on monotherapy have been reported to date, although less than thirty have been described in detail. 7.14

We now report malformations in two newborns after intrauterine exposure to valproic acid alone.

\section{CASE Reports}

Patient 1: Baby F, a girl, was born after a full-term uneventful pregnancy to a 26-year-old woman with primary generalized epilepsy.
The mother's convulsive disorder was well controlled throughout pregnancy with valproic acid ( $2 \mathrm{~g}$ daily) without any other medication: blood levels ranged from 436 to $755 \mathrm{umol} / \mathrm{L}$ (therapeutic range: $350-700 \mathrm{umol} / \mathrm{L}$ ). Two years prior to this pregnancy, a spontaneous abortion occurred at 17 weeks of gestation; at that time. the mother was taking the same medication at the same dose, with blood levels measured between 1032 and $1198 \mathrm{umol} / \mathrm{L}$. The family history was negative.

The Apgar score was 4,6 and 8 at 1,5 and 10 minutes. Birth weight was $2740 \mathrm{gm}$ ( $3 \mathrm{rd}$ percentile), length $50 \mathrm{~cm}$ (50th percentile) and head circumference $34 \mathrm{~cm}$ (50th percentile).

Physical examination revealed dysmorphic features including an old-looking facies, hypertelorism, antimongoloid palpebral fissures, a naevus flammeus on the forehead, flat portwine palpebral and nasal hemangiomas, a broad-based nose with anteverted nostrils, and thin lips with labial commissures pointing downwards. The ears were small and low-set with abnormal curvature of the pinna. The nipples were widely spaced. Numerous limb anomalies were present: arachnodactyly, radial deviation of the hands at the wrists, triphalangeal thumbs, cutaneous syndactyly of the second and third digits, a flexion contracture of the third right digit at the joint involving the proximal and intermediate phalanx, a right palm transverse crease and slightly overlapping second toes.

Further investigations were non-contributory except for cerebral CT scan which showed a septum pellucidum cyst and mild dilatation of the ventricular system. The karyotype was normal. 
When seen at 8 months of age (Figure 1), neurological examination showed no specific signs except for mild delay in motor development. Her length was $70 \mathrm{~cm}$ (75 percentile) and her weight $7200 \mathrm{gm}$ (25th percentile).

Patient 2: A twenty-year-old woman with a generalized seizure disorder received valproic acid ( $1750 \mathrm{mg}$ daily) throughout her pregnancy; she had no seizures with that regimen. Labor was induced at 38 weeks because of absent fetal movements. She gave birth to baby A-B, a boy weighing $2100 \mathrm{gm}$. The Apgar score was 6,8 and 8 at 1,5 and 10 minutes respectively.

The infant was admitted to our hospital at 11 weeks of age because of frequent episodes of cyanosis while crying or immediately after bottle feeding. The weight was $3880 \mathrm{gm}$ (below 3 rd percentile) and the head circumference $38 \mathrm{~cm}$ ( $3 \mathrm{rd}$ percentile). The baby manifested mild respiratory distress with nasal flaring and use of intercostal muscles. Examination revealed hypertelorism, micrognathia, a short neck, low set ears with posterior rotation, thin upper lip, a high-arched palate, and hypoplasia of the distal phalanx of the 2 nd and 4 th digits.

Cerebral CT scan showed moderate atrophy. An EEG revealed focal epileptic activity. The karyotype was normal. Dilatation of the coronary sinus without associated cardiac defects was found by echocardiography. Laryngoscopy showed severe laryngeal hypoplasia and tracheomalacia with external compression suggesting an aberrant innominate artery. The baby presented severe larynogospasm following the last procedure and required endotracheal intubation for 10 days. The infant died at 19 weeks of age after massive pulmonary aspiration. An autopsy confirmed the anomalies described above including the severe laryngeal hypoplasia and a left superior vena cava draining in the

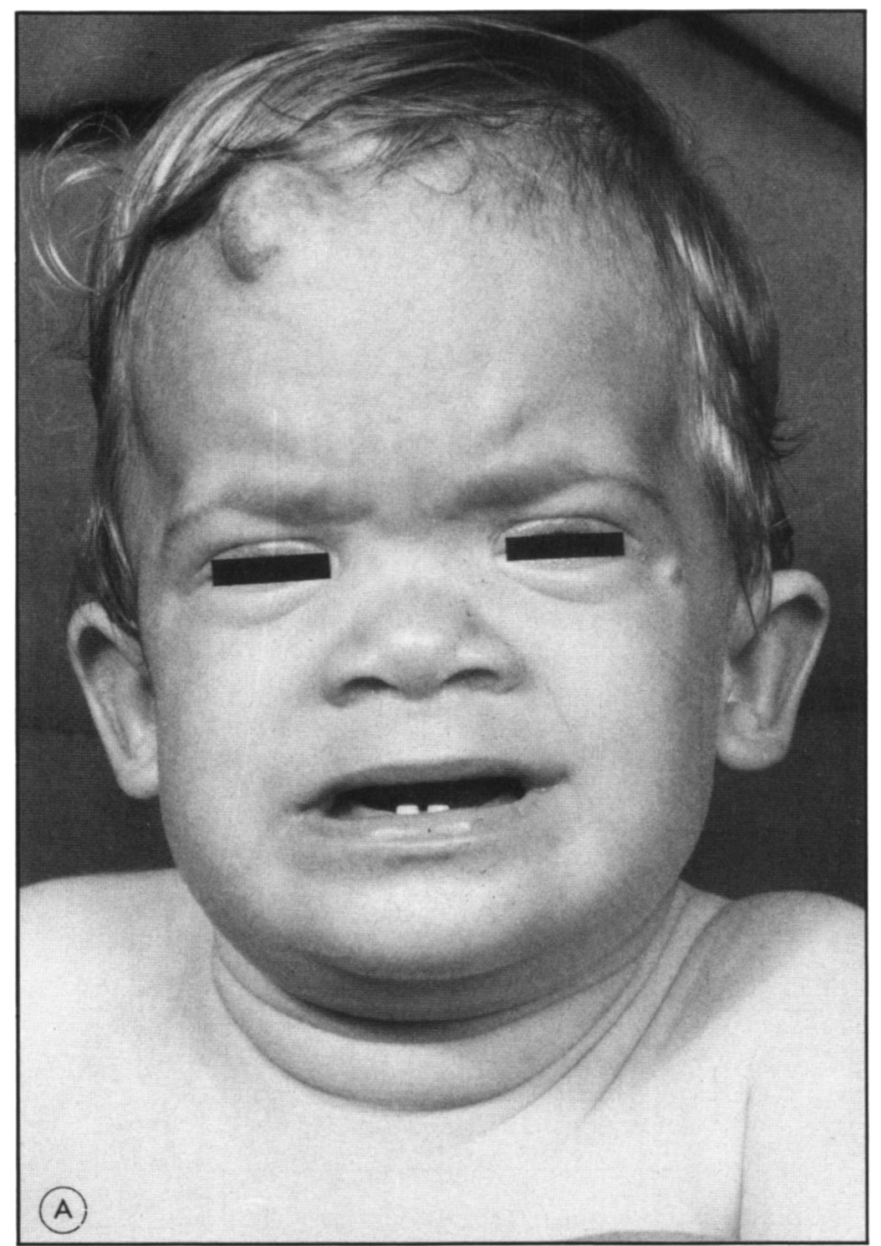

coronary sinus, abnormal lobulation of the right lung and left hydronephrosis.

No other congenital malformations were known to have occurred in the family.

\section{DISCUSSION}

Experiments have shown valproic acid to be teratogenic in rodents when given in large doses. ${ }^{1}$ The effects appear to be dose related. The incidence of major malformations rises from 4 to 16 percent in mouse offspring with maternal intake varying between 75 and $600 \mathrm{mg} / \mathrm{kg} /$ day. Defects include vertebral anomalies (particularly lumbar spinal fusions), rib defects, microcephaly, encephaloceles, renal abnormalities (especially hydronephrosis and renal agenesis) and cleft palates. ${ }^{1}$ Growth retardation is commonly observed. ${ }^{17}$

While results from experimental animal models cannot be applied indiscriminately to humans, there has been some evidence in recent years of human teratogenicity associated with first-trimester use of valproic acid. The first report suggesting an association between congenital malformations and valproic acid was published in 1980 by Dalens et al $^{7}$ and subsequent isolated cases seem to substantiate this possibility. We have drawn a list (Table 1) of congenital anomalies reported since 1980 among 46 patients exposed to valproic acid monotherapy

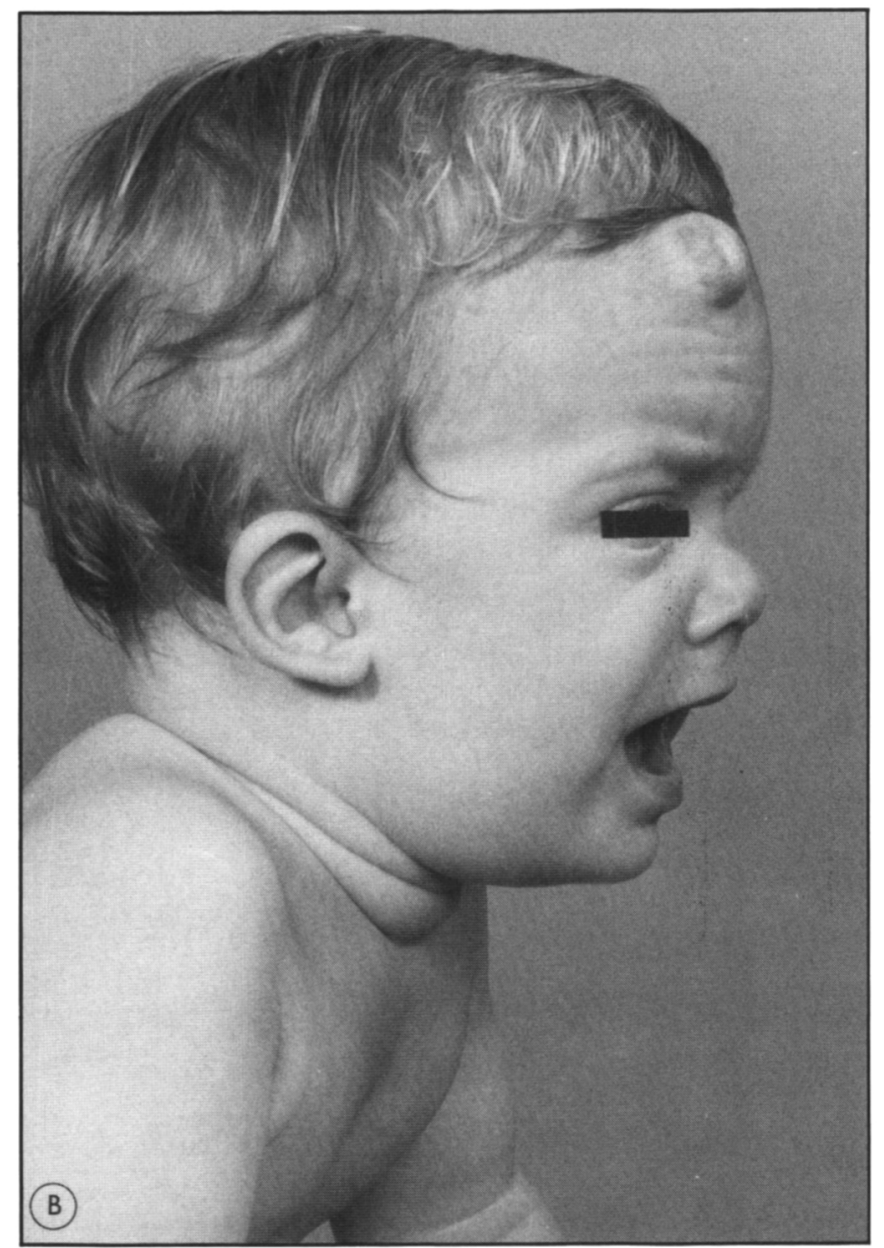

Figure I (A and B) - Patient l at 8 months of age: Cranio facial features included coarse facies, relative hypertelorism, antimongoloid palpebral fissures, frontal strawberry hemangioma, and a broad-based nose with small low-set ears. 
during fetal life (cases associated with concomitant use of other anticonvulsants are excluded). Patients were included if they had at least one major anomaly or more than three minor anomalies. While some reports are detailed, others may have overlooked minor birth defects in their descriptions, ${ }^{10.12}$ while stressing major malformations such as spina bifida and congenital heart defects.

Inspection of this list of human fetal anomalies does not yet permit us to recognize a consistent spectrum of birth defects associated with maternal valproic acid monotherapy. None of the most frequently reported anomalies was encountered in more than a third of the malformed babies. Facial dysmorphism is frequent but heterogeneous. The facial phenotype described and found so specific as to be named "fetal valproate syndrome" by $\mathrm{Di}$ Liberti et $\mathrm{al}^{14}$ differs in many respects from other descriptions. ${ }^{16}$ Jäger-Roman et al ${ }^{16}$ observed brachycephaly, high forehead, shallow orbits, hypertelorism and microstomy, whereas Di Liberti et al $^{14}$ did not.

Congenital heart defects are present in 22\% (10/46) of the patients, but are, along with cleft lip and palate, among the most common anomalies encountered in infants born to epileptic mothers in general. ${ }^{18}$ Although abnormalities of the extremities and digits are described in about a fourth (12/46) of the cases, they are very diverse. The "distinct" digital anomalies observed by Jäger-Roman et al ${ }^{15}$ consist of long, thin, partly overlapping fingers and toes and hyperconvex nails but have not been described in other reports. Strikingly, besides the nine cases of spina bifida reported by Robert et al ${ }^{12}$ from Lyon (France), only 2 of the 37 other children exposed to valproic acid monotherapy were born with this anomaly. The reports from Lyon must be taken seriously although the assessment of their findings requires more information. Finally, a few of the anomalies - laryngeal hypoplasia (patient 2 ), duodenal atresia ${ }^{13}$ - are so uncommon that they may represent isolated developmental defects not related to valproic acid intake.

Although there is general agreement that the incidence of malformed infants is increased in epileptic mothers receiving antiepileptic drugs during their pregnancy as opposed to those unmedicated, ${ }^{18}$ the precise role played by the anticonvulsants remains unclear. Among the risk factors for teratogenesis that must be considered are the inherent effect of the drugs, the occurrence of frequent convulsions during pregnancy, the complications of pregnancy in itself and the socioeconomic status of the pregnant epileptic woman. ${ }^{18}$ To date, trimethadione is the only anticonvulsant which is considered absolutely contraindicated in pregnancy because of an acknowledged high risk of teratogenicity. ${ }^{18}$

In summary, from our observations and review of the available literature we conclude that valproic acid has probable teratogenic potential in humans. However, because of the wide spectrum of anomalies described and the small number of cases reported, it is not yet possible to delineate definitively a fetal

Table 1: Reported anomalies among 46 patients exposed to valproic acid monotherapy during fetal life

\begin{tabular}{|c|c|c|c|c|c|c|c|c|c|c|c|c|}
\hline & No. of MALFORMED babies & $0^{4}$ & $\int^{4}+4$ & 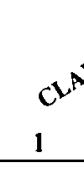 & 5 & ${ }^{2}$ & ${ }_{R}^{\prime \prime} \mathrm{O}^{B}$ & $a^{2}$ & ol & $\frac{1}{(x)}$ & $\int^{3}$ & $\int^{5}$ \\
\hline 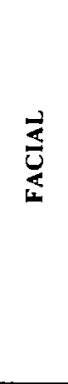 & $\begin{array}{l}\text { ANOMALY } \\
\text { Ears (low set or malf.) } \\
\text { Nose (small, broad) } \\
\text { Hypertelorism } \\
\text { Micro/retrognathia } \\
\text { Microstomy } \\
\text { Brachycephaly } \\
\text { High forehead } \\
\text { Shallow orbits } \\
\text { Long upper lip } \\
\text { Thin upper vermilion b. } \\
\text { Other dysmorphisms }\end{array}$ & $\begin{array}{l}+\left(1^{*}\right) \\
+(1) \\
-(1) \\
+ \\
-(1) \\
+(1) \\
- \\
+(1)\end{array}$ & $\begin{array}{l}+(1) \\
- \\
+(1) \\
- \\
- \\
= \\
- \\
- \\
+(1)\end{array}$ & $\begin{array}{l}- \\
+(1) \\
- \\
- \\
+(1) \\
- \\
- \\
-\end{array}$ & $\begin{array}{l}- \\
- \\
- \\
- \\
- \\
- \\
-\end{array}$ & $\begin{array}{l}- \\
- \\
+(1) \\
- \\
- \\
- \\
- \\
-\end{array}$ & $\begin{array}{l}- \\
- \\
- \\
- \\
- \\
- \\
-\end{array}$ & $\begin{array}{l}- \\
- \\
- \\
- \\
- \\
- \\
-\end{array}$ & $\begin{array}{l}+(3) \\
+(3) \\
- \\
- \\
+(1) \\
- \\
- \\
+(3) \\
+(4) \\
+(4)\end{array}$ & $\begin{array}{l}+(1) \\
+(1) \\
+(1) \\
- \\
+(1) \\
= \\
= \\
+(1) \\
+(1) \\
+(1)\end{array}$ & $\begin{array}{l}+(3) \\
+(8) \\
+(5) \\
+(2) \\
+(3) \\
+(3) \\
+(4) \\
+(3) \\
+(5) \\
+(5) \\
+(7)\end{array}$ & $\begin{array}{l}+(2) \\
+(1) \\
+(2) \\
+(2) \\
- \\
-(1) \\
-(2) \\
+(2) \\
-\end{array}$ \\
\hline 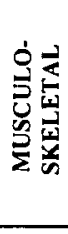 & $\begin{array}{l}\text { Abdominal wall weakness } \\
\text { Long thin digits } \\
\text { Overlapping digits } \\
\text { Hyperconvex nails } \\
\text { Other digits anomalies } \\
\text { Abnormal extremities } \\
\text { Thoracic cage anomalies }\end{array}$ & $\begin{array}{l}- \\
- \\
\overline{-} \\
+(1) \\
+(2) \\
+(1)\end{array}$ & $\begin{array}{l}+(6) \\
- \\
- \\
+(1) \\
+(1) \\
-\end{array}$ & $\begin{array}{l}- \\
- \\
\overline{-} \\
+1) \\
-\end{array}$ & $\begin{array}{l}- \\
- \\
- \\
- \\
-\end{array}$ & $\begin{array}{l}- \\
- \\
- \\
+(2) \\
+(2) \\
-\end{array}$ & $\begin{array}{l}- \\
- \\
- \\
- \\
-\end{array}$ & $\begin{array}{l}+(1) \\
- \\
- \\
- \\
- \\
-\end{array}$ & $\begin{array}{l}+(1) \\
- \\
- \\
+(1) \\
+(1) \\
-\end{array}$ & $\begin{array}{l}- \\
- \\
- \\
+(1) \\
-\end{array}$ & $\begin{array}{l}- \\
+(3) \\
+(2) \\
+(2) \\
+(3) \\
+(1) \\
+(3) \\
\end{array}$ & $\begin{array}{l}- \\
+(1) \\
+(1) \\
-(2) \\
+(1) \\
-\end{array}$ \\
\hline$z^{\infty}$ & $\begin{array}{l}\text { Spina bifida } \\
\text { Microcephaly }\end{array}$ & $+\overline{(1)}$ & $\overline{+(1)}$ & - & $\stackrel{(1)}{-}$ & - & $\begin{array}{c}+(9) \\
-\end{array}$ & - & - & $\overline{+(1)}$ & $\begin{array}{l}+(1) \\
+(1) \\
\end{array}$ & - \\
\hline 号完 & $\begin{array}{l}\text { Cong. heart defect } \\
\text { Hemangiomas } \\
\text { Aberrant inn. artery }\end{array}$ & $\begin{array}{l}- \\
-\end{array}$ & $\begin{array}{l}+(1) \\
+(1) \\
-\end{array}$ & $\begin{array}{l}+(1) \\
-\end{array}$ & - & $+(1)$ & $\begin{array}{l}+(4) \\
- \\
-\end{array}$ & $\begin{array}{l}- \\
+(1) \\
-\end{array}$ & $\begin{array}{l}+(1) \\
+(1) \\
-\end{array}$ & $\begin{array}{l}- \\
+(1) \\
-\end{array}$ & $\begin{array}{l}+(2) \\
- \\
-\end{array}$ & $\begin{array}{l}- \\
+(1) \\
+(1)\end{array}$ \\
\hline$\frac{\mathscr{2}}{\sqrt[3]{\mathbf{x}}}$ & $\begin{array}{l}\text { Renal hypoplasia } \\
\text { Hypospadias } \\
\text { Intrauterine growth retardation } \\
\text { Duodenal atresia }\end{array}$ & $\begin{array}{l}- \\
- \\
-\end{array}$ & $\begin{array}{l}- \\
- \\
-\end{array}$ & $\begin{array}{l}- \\
- \\
-\end{array}$ & $\begin{array}{l}- \\
- \\
-\end{array}$ & $\begin{array}{l}+(1) \\
+(1) \\
+(1) \\
-\end{array}$ & $\begin{array}{l}- \\
- \\
-\end{array}$ & $\begin{array}{c}- \\
\overline{-} \\
+(1)\end{array}$ & $\begin{array}{l}- \\
+(1) \\
+(1) \\
-\end{array}$ & $\begin{array}{l}- \\
- \\
-\end{array}$ & $\begin{array}{c}- \\
+(4) \\
+(1) \\
-\end{array}$ & $\begin{array}{c}- \\
-(1) \\
-\end{array}$ \\
\hline
\end{tabular}

*Numbers in parentheses correspond to the number of patients affected. 
valproate syndrome. Quantification of risk and association with risk co-factors requires further investigation. The use of valproic acid during pregnancy should be avoided whenever satisfactory alternatives exist for management of maternal seizure disorders.

\section{ACKNOWLEDGEMENTS}

We thank Dr. Gerald Ahronheim for his valuable comments, and Sylvie Morin for her expert secretarial assistance.

\section{REFERENCES}

1. Whittle BA. Pre-clinical teratological studies on sodium valproate (Epilim) and other anticonvulsants. In: Legg NJ, ed. Clinical and pharmacological aspects of sodium valproate (Epilim) in the treatment of epilepsy. MCS consultants, Turnbridge Wells, 1976: 105-110.

2. Brown NA, Keo J, Fabro S. Teratogenic potential of valproic acid. Lancet 1980; 1: 660-661.

3. Bruckner A, Lee YJ, O'Shea KS, et al. Teratogenic effects of valproic acid and diphenylhydantoin on mouse embryos in culture. Teratology 1983; 27: 29-42.

4. Robert E, Guibaud P. Maternal valproic acid and congenital neural tube defects. Lancet 1982; 2: 937.

5. Centers for disease control. Valproate: A new cause of birth defects - report from Italy and follow-up from France. MMWR 1983; 32: 438-439.
6. Lindhout $D$, Schmidt D. In-utero exposure to valproic and neural tube defects. Lancet 1986; 1: 1392-1393.

7. Dalens B, Raynaud EJ, Gaulme J. Teratogenecity of valproic acid. J Pediatr 1980; 97: 332-333.

8. Nau H, Rating D, Koch S, et al. Valproic acid and its metabolites: placental transfer, neonatal pharmacokinetics, transfer via mother's milk and clinical status in neonates of epileptic mothers. J Pharmacol Exp Ther 1981; 219: 768-777.

9. Clay SA, McVie R, Chen H. Possible teratogenic effect of valproic acid; J Pediatr 1981: 99: 828.

10. Stanley $\mathrm{OH}$, Chambers TL. Sodium valproate and neural tube defects. Lancet 1982; 2: 1282.

11. Bailey CJ, Pool RW, Poskitt EME, et al. Valproic acid and fetal abnormality. Br Med J 1983; 286: 190.

12. Robert E, Rosa F. Valproate and birth defects. Lancet 1983; 2 : 1142.

13. Bantz EW. Valproic acid and congenital malformations. Clin Pediatr 1984; 23: 352-353.

14. Di Liberti JH, Farndon PA, Dennis NR, et al. The fetal valproate syndrome. Am J Med Genet 1984; 19: 473-481.

15. Tein I, MacGregor DL. Possible valproate teratogenecity. Arch Neurol 1985; 42: 291-293.

16. Jäger-Roman, Deichl A, Jakob S, et al. Fetal growth, major malformations, and minor anomalies in infants born to women receiving valproic acid. J Pediatr 1986; 108: 997-1004.

17. Löscher W, Nau H, Marescaux C, et al. Comparative evaluation of anticonvulsant and toxic potencies of valproic acid and 2-envalproic acid in different animal models of epilepsy. Eur $\mathrm{J}$ Pharmacol 1984:99: 211-218.

18. Dalessio DJ. Seizure disorders and pregnancy. N Engl J Med 1985; 312: 559-563. 